\title{
Leatherback turtles (Dermochelys coriacea) in the Gulf of Venezuela: an updated stranding assessment 2001-2014
}

\author{
Daniela Rojas-Cañizales ${ }^{1,2,3}$, Nínive Espinoza-Rodríguez ${ }^{1,2}$, María A. RodríGuez ${ }^{1,3}$, Jordano Palmar ${ }^{1}$, \\ María G. Montiel-Villalobos ${ }^{1,4}$, Natalie E. Wildermann $1,3,5,6$ and Héctor Barrios-Garrido ${ }^{1,3,7, *}$
}

\begin{abstract}
${ }^{1}$ Grupo de Trabajo en Tortugas Marinas del Golfo de Venezuela (GTTM-GV), Maracaibo, Venezuela. ${ }^{2}$ Centro de Rescate de Especies Marinas Amenazadas (CREMA), Calle 114, $1.5 \mathrm{~km}$ Norte, 40201, Barva, Costa Rica. ${ }^{3}$ Laboratorio de Ecología General, Centro de Modelado Científico (CMC), Facultad Experimental de Ciencias, Universidad del Zulia (LUZ), 4004, Maracaibo, Venezuela. ${ }^{4}$ Laboratorio de Ecología y Genética de Poblaciones, Centro de Ecología, Instituto Venezolano de Investigaciones Científicas (IVIC), 1020-A, Caracas, Venezuela. ${ }^{5}$ Texas Sea Grant at Texas A\&M University, 4115 TAMU, College Station, TX 77843- 4115, USA. ${ }^{6}$ Harte Research Institute for Gulf of Mexico Studies, 6300 Ocean Dr, Corpus Christi, TX 78412, USA. ${ }^{7}$ TropWATER, Centre for Tropical Water and Aquatic Ecosystem Research; College of Marine and Environmental Sciences, James Cook University, Townsville, Queensland 4811, Australia
\end{abstract}

Marine and

Fishery Sciences

MAFIS

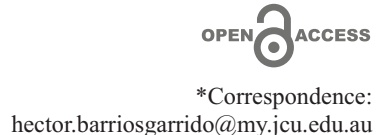

Received: 15 January 2021

Accepted: 9 February 2021

ISSN 2683-7595 (print) ISSN 2683-7951 (online)

https://ojs.inidep.edu.ar

Journal of the Instituto Nacional de Investigación y Desarrollo Pesquero (INIDEP)

This work is licensed Commons AttributionNonCommercial-ShareAlike 4.0 International License
ABSTRACT. Leatherback turtle (Dermochelys coriacea) is highly impacted by fisheries' bycatch worldwide. This study updates and estimates the leatherback turtle stranding records from 2001 to 2014 in the Gulf of Venezuela. Eighty-seven stranded leatherback turtles were documented in the coast of the Gulf of Venezuela. Immature leatherback turtles were the most affected (85.5\%) and the highest number of strandings were recorded during the dry season (56.3\%). Our findings represent the minimum estimate of stranding events for the Gulf of Venezuela, especially considering the current lack of fisheries regulations. This is the latest update for the leatherback turtle strandings in the Gulf of Venezuela and could help to create new management solutions in the area aiming to minimize the impact on leatherback turtle populations in the Caribbean.

Key words: Immature, marine turtle, strand, IUU fishing, Guajira Peninsula, southern Caribbean.

Tortugas cardón (Dermochelys coriacea) en el Golfo de Venezuela: una actualización sobre las evaluaciones de los varamientos 2001-2014

RESUMEN. La tortuga cardón (Dermochelys coriacea) está altamente impactada por las capturas incidentales a nivel global. Este estudio actualiza y calcula los registros de varamientos de la tortuga cardón desde 2001 hasta 2014 en el Golfo de Venezuela. Se contabilizaron 87 animales varados en la costa del Golfo de Venezuela. El segmento poblacional más afectado fueron los individuos inmaduros $(85,5 \%)$ y el mayor número de registro de varamientos ocurrió en época de sequía $(56,3 \%)$. Nuestros resultados representan el mínimo estimado de muertes por varamientos para el Golfo de Venezuela, especialmente dadas las condiciones actuales de ausencia total de regulaciones formales a las pesquerías. El presente trabajo representa la más reciente evaluación de los varamientos para esta especie en el Golfo de Venezuela, la cual podría ayudar a crear nuevas y mejores medidas de manejo en el área de trabajo, disminuyendo el impacto que afectan a las poblaciones de tortuga cardón en el Caribe.

Palabras clave: Juveniles, tortuga marina, varamiento, pesca INDNR, Península de La Guajira, Caribe sur. 
The leatherback turtle (Dermochelys coriacea) is one of the five species of marine turtles that use the feeding ground areas in the Gulf of Venezuela (Guada and Sole 2000). It is currently listed as Endangered at regional level and also at national scale by the International Union for Conservation of Nature (IUCN) (NALWG 2019), and by the Red Book of Venezuelan species (RondónMedicci et al. 2015).

Most of the information about the species in the Gulf of Venezuela has been derived from stranding data (Acuña and Toledo 1994; GarcíaCruz et al. 2020). However, stranding trends are still in early stage of evaluation. Previous research found that there is still a lack of information regarding the seasonality and impacts of artisanal fishing over this species in the study area. This study aims to update the results presented by Barrios-Garrido and Montiel-Villalobos (2016) and merge records from 2001 to 2014 in the Gulf of Venezuela.

Following previous research and protocol, this study was carried out in the three main areas at the Venezuelan Guajira Peninsula (Gulf of Venezuela): the Upper Guajira; Middle Guajira; and Low Guajira (Barrios-Garrido and MontielVillalobos 2016) (Figure 1). We covered an extension of $188.7 \mathrm{~km}$ of coastline $\left(11^{\circ} 36^{\prime} 27.5^{\prime \prime}\right.$ $\left.\mathrm{N} ; 71^{\circ} 53^{\prime} 48.7^{\prime \prime} \mathrm{W}\right)$ including 14 landing sites, villages and fishing ports. The Gulf of Venezuela has two distinct seasons: a dry season $(100 \mathrm{~mm}$ mean rainfall from December to April) and a rainy season (200 $\mathrm{mm}$ mean rainfall from May to November) (Rodríguez and Morales 2000). Also, this marine area is considered a key foraging ground for leatherback turtles in Venezuela (Guada and Solé 2000; Barrios-Garrido and Montiel-Villalobos 2016).

We evaluated leatherback turtle stranding data and merged stranding network databases: for 2001-2007 assessed by Barrios-Garrido and Montiel-Villalobos (2016); plus data collected between 2008-2014 by the NGO Marine Turtle Working Group in the Gulf of Venezuela. We assessed each stranded animal based on formal stranding register: GPS location, biometrical measurements, and life stage of the stranded turtle (immature or adult-size animals) (see details in Barrios-Garrido and Montiel-Villalobos 2016). A t-test was conducted to determine differences among the number of records during the years of the sampling period.

We evaluated the geographical and temporal (annually and quarterly) distribution of the strandings across the three main areas. Additionally, strandings were classify as: 0 (alive); 1 (alive, but subsequently died); 2 (dead, fresh carcass); 3 (dead; carcass fair; decomposing but internal organs intact); 4 (dead, carcass poor condition; advanced decomposition); 5 (dead, mummified carcass with skin holding bones together); 6 (dead, disarticulated bones) (Meager and Limpus 2012). Finally, strandings were categorized based on the cause of stranding: unknown or human activity-linked (e.g., bycatch) (Kotch et al. 2006).

We found 87 stranded leatherback turtles along the coastline of the Gulf of Venezuela. The highest number of encounters was reported in 2003 $(25.3 \%, \mathrm{n}=22)$ and $2013(17.2 \%, \mathrm{n}=15)$ (Figure 2), while in 2004, 2010 and, 2012 no stranding events were documented. Significant differences were found among the number of records throughout the years of the sampling period $(\mathrm{t}-$ value $=4.24 ; \mathrm{df}=10 ; p=0.001719$ ).

The highest percentage of strandings was recorded during the dry season $(56.3 \%, \mathrm{n}=49)$; with most encounters documented in February and April $(52.9 \%, \mathrm{n}=46)$ (Figure 2). Finally, most stranding encounters were in categories 3 to $6(78.9 \%, \mathrm{n}=15)$ and four among the categories $0(5.5 \%, \mathrm{n}=1), 1(5.5 \%, \mathrm{n}=1)$, and $2(11.1 \%$, $\mathrm{n}=2)$. The majority of the standings' causes were unknown $(63.2 \%, \mathrm{n}=55)$ and the remains presented evidence of human interactions $(36.8 \%$, $\mathrm{n}=32$ ), mainly bycatch and intentional take.

Leatherback strandings were more frequent in the Low Guajira $(58.6 \%, \mathrm{n}=51)$, followed by the Upper Guajira $(33.3 \%, \mathrm{n}=29)$, with sporadic 


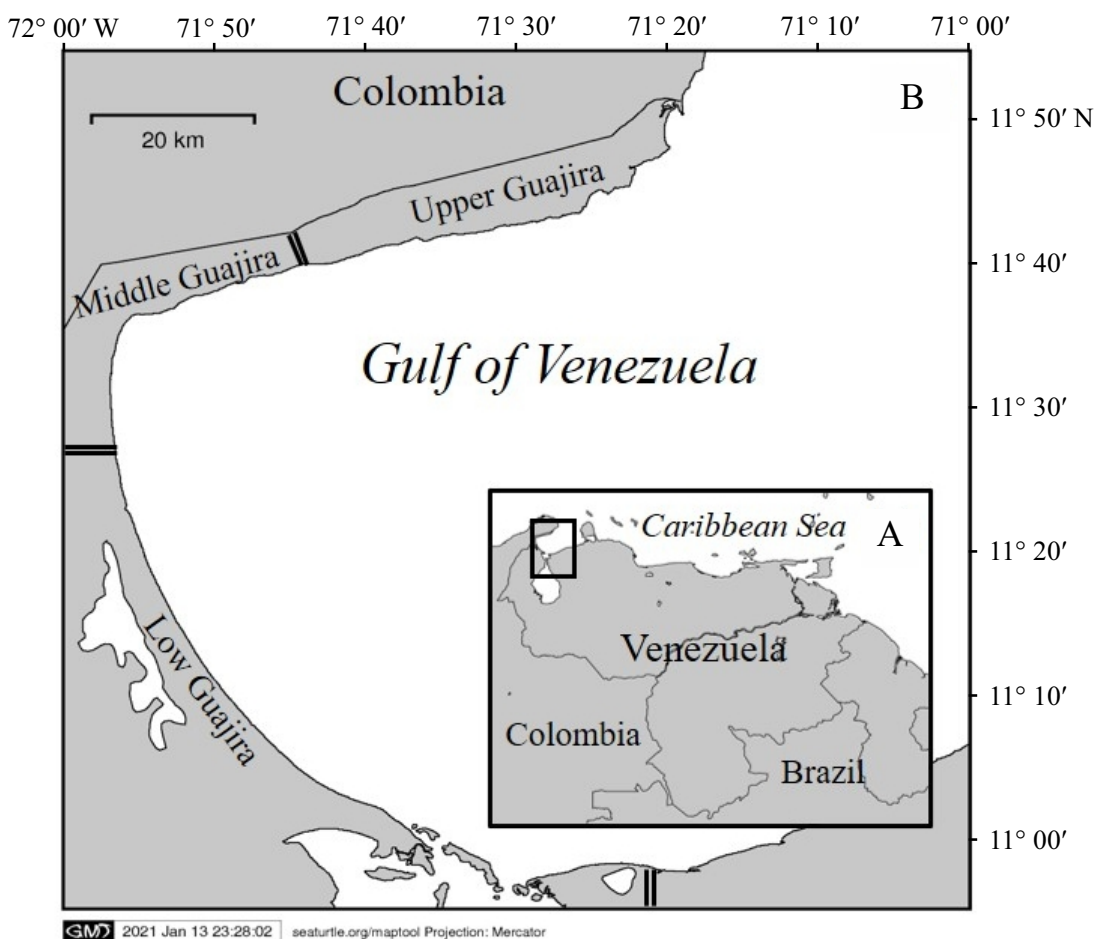

Figure 1. A) Geographical location of the study area. B) Detailed map including the three main locations in the Gulf of Venezuela separated by double-lines (Upper Guajira, Middle Guajira, and Low Guajira). Map created using Maptool (2002. SEATURTLE.ORG, Inc. Available at http://www.seaturtle.org/maptool/).

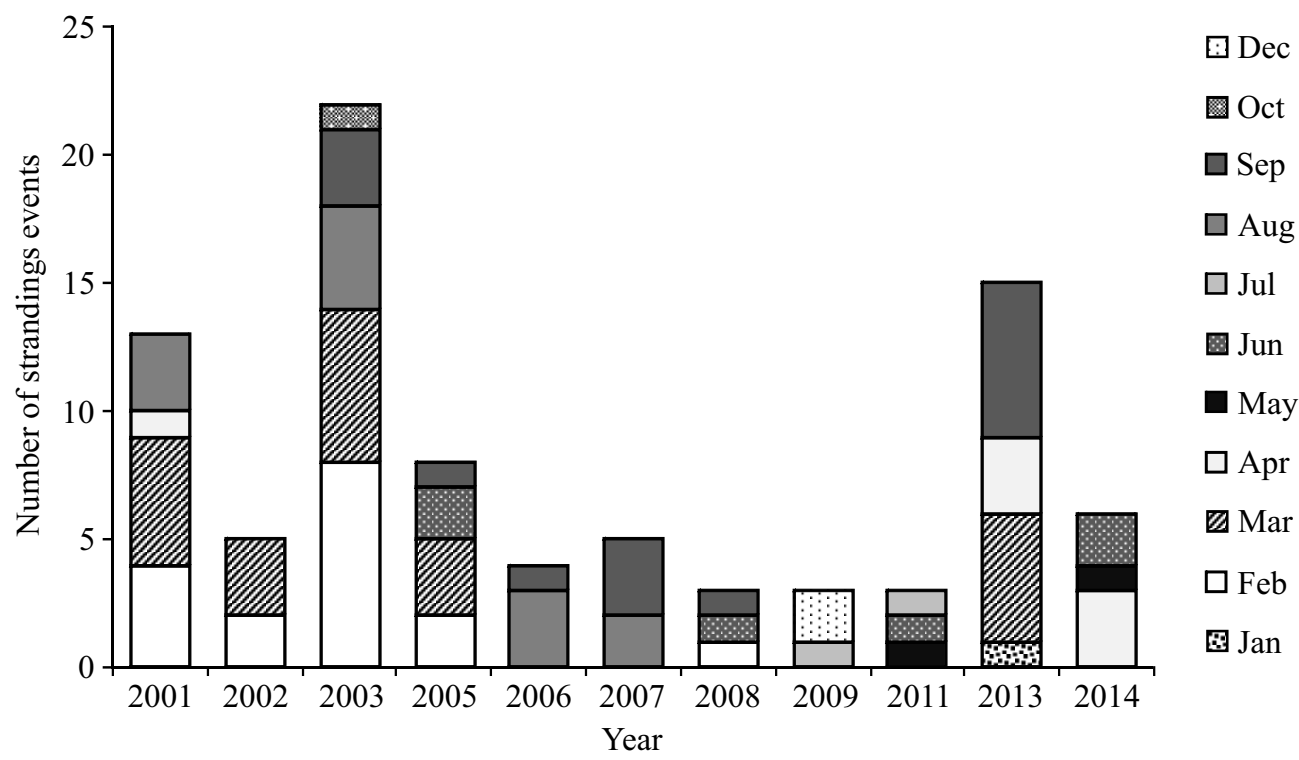

Figure 2. Annually and monthly stranding events of leatherback turtles (Dermochelys coriacea) between 2001 and 2014 along the coastline of the Gulf of Venezuela $(\mathrm{N}=87)$. 
events in the Middle Guajira $(8.0 \%, \mathrm{n}=7)$ (Figure 3). Mean curved carapace length $(\mathrm{CCL} \pm \mathrm{SD})$ was $125.6 \mathrm{~cm} \pm 21.4$, ranging between $80-195 \mathrm{~cm}$ $(\mathrm{n}=55)$. Based on the measurements taken, most of the stranded turtles were immatures $(85.5 \%$, $\mathrm{n}=47)$ with only $14.5 \%(\mathrm{n}=8)$ adults.

Eighty-seven stranded leatherback turtles have been documented in the coast of Gulf of Venezuela. The number of encounters found was low compared with leatherback bycatch in Trinidad Tobago and the Eastern Caribbean (Gass and Eckert 2006; Connor Blades et al. 2019). The number of leatherback turtles stranded found was likely a conservative estimate, especially considering that fisheries-related mortality is usually partially reported (Hamann et al. 2010; Hamelin et al. 2017; Connor Blades et al. 2019). Further research is necessary to understand how this is affecting the species regionally.

Most of the stranded turtles were documented in the Low and Upper Guajira, possibly linked to local currents, tides, winds converge in both areas, and offshore fisheries in the Low Guajira (Barrios-Garrido and Montiel-Villalobos 2016). Only seven leatherbacks were documented in the Middle Guajira, may be related to biophysi- cal characteristics of this area (Rojas-Cañizales et al. 2020). Winds and sea currents have an important role in where or whether a marine turtle get stranded or not (Epperly et al. 1996). It is necessary to assess local oceanographic variables to understand how leatherback turtle carcasses move within the Gulf of Venezuela to monitor key stranding areas.

A large portion of recorded leatherback turtles $(85.5 \%)$ was immature. The Gulf of Venezuela is likely a migratory route and a foraging area. It is possible that the immature leatherbacks were using this area to move with adult individuals (Barrios-Garrido and Montiel-Villalobos 2016), in a similar way as previously documented by James et al. (2005) in Canadian waters. The number of immature leatherbacks stranded was alarming and could negatively impact Caribbean populations, as it occurred in the Eastern Pacific Regional Management Unit (Wallace et al. 2013). Further research such as satellite tracking is needed to understand the movements and the impact at regional scale of the stranding trend.

Most records documented occurred during the dry season. This seasonality might be related to the leatherback nesting season that starts in March

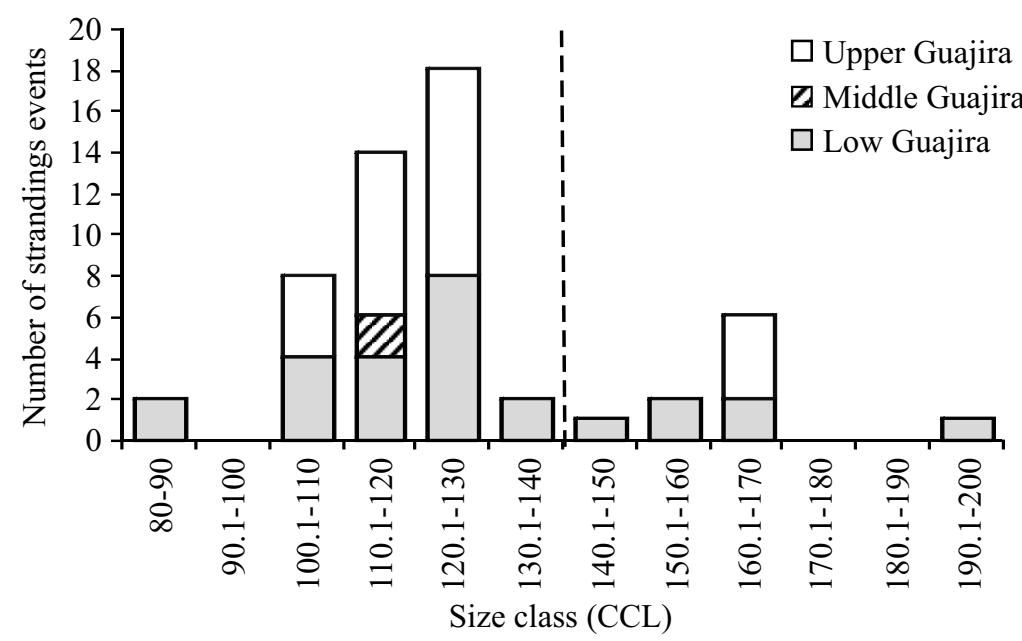

Figure 3. Size intervals $(\mathrm{cm})$ of stranded leatherbacks (Dermochelys coriacea) found in the Upper Guajira, Middle Guajira, and Low Guajira $(N=54)$. Dashed line represents the minimum size $(<145 \mathrm{~cm}$ of CCL $)$ recorded for leatherback nesters in Atlantic Ocean (Eckert 2002; Stewart et al. 2007). 
at surrounding nesting beaches in the Caribbean (Rondón-Medicci et al. 2011, 2015; Borrero-Avellaneda et al. 2015). Leatherback turtles travelled extensively from the Caribbean throughout the Atlantic increasing the interaction with fisheries (Hays et al. 2004; Hamelin et al. 2017; Connor Blades et al. 2019). Morover, these movements might be associated to local food occurrence and distribution (Fossette et al. 2008). Barrios-Garrido et al. (2020) reported an adult leatherback turtle that was tagged in French Guyana and found later in the Upper Guajira, therefore suggesting that leatherback turtles use the foraging area after reproductive seasons. It is necessary to study the connections between the Gulf of Venezuela and the nesting areas in the Caribbean and Atlantic to identify hotspots for the species and create regional management plans.

Most of stranded leatherbacks documented were found in an advanced state of decomposition $(78.9 \%)$, being difficult to determine the cause of death (Veléz-Rubio et al. 2013). Commonly, stranding events are closely influenced by fishery interactions (Nicolau et al. 2016), which it is likely to be occurring in the Gulf of Venezuela; however, due to the nature of our data it is difficult to establish these interactions as the main cause of death. Currently, there is an information gap on the consequences of bycatch and intentional take in the area and its implications in the ecosystem. Applying standardized protocols could provide useful information in the future to better understand the main cause of strandings in the Gulf of Venezuela.

\section{ACKNOWLEDGEMENTS}

We thank to all the fishers, Wayuú clan leaders, and GTTM-GV's volunteers that contributed to this study. This research was authorized by Venezuela's Environmental Ministry via scientific licenses and 828, 886, and 1224.

\section{REFERENCES}

Acuña AJ, Toledo JR. 1994. Rare records of Dermochelys in the Gulf of Venezuela. Marine Turtle Newsletter. 64: 10.

Barrios-Garrido H, Becker P, BJorndal KA, Bolten AB, Diez C, Espinoza-Rodríguez N, Fastigi M, Gray J, Harrison E, Hart KA, et al. 2020. Sources and movements of marine turtles in the Gulf of Venezuela: Regional and local assessments. Reg Stud Mar Sci. 36: 101318.

Barrios-Garrido H, Montiel-Villalobos MG. 2016. Strandings of leatherback turtles (Dermochelys coriacea) along the western and southern coast of the Gulf of Venezuela. Herpetol Conserv Biol. 11: 244-252.

Borrero-Avellaneda WJ, Patiño EA, Guerra ML, BÁEz LP, GouriYu WA. 2015. Primeras anotaciones de la anidación de tortugas marinas en las playas de Punta Cañon, Bahía Hondita y Punta Gallinas, alta Guajira, Colombia. Rev Biodivers Neotrop. 5 (2): 111-119.

Connor Blades D, Walcott J, Horrocks JA. 2019. Leatherback bycatch in an Eastern Caribbean artisanal longline fishery. Endang Species Res. 40: 329-335.

ECKERT SA. 2002. Distribution of juvenile leatherback sea turtle Dermochelys coriacea sightings. Mar Ecol Prog Ser. 230: 289-293.

EpPerly S, Chester AJ, Cross FA, MERriner JV, Tester PA, Churchill JH. 1996. Beach strandings as an indicator of at-sea mortality sea turtles. Bull Mar Sci. 59: 289-297.

Fossette S, Gaspar P, Handrich Y, Maho Y Le, GeORGES JY. 2008. Dive and beak movement patterns in leatherback turtles Dermochelys coriacea during internesting intervals in French Guiana. J Anim Ecol. 77: 236-246.

García-Cruz MA, Arias-Ortiz A, Balladares C, Barrios-Garrido H, Caputo M, Diaz O, Espinoza-Rodríguez N, Fajardo E, Guada 
H, Moraday J, et al. 2020. Venezuela. In: Nalovic MA, Ceriani SA, Fuentes MMPB, Pfaller JB, Wildermann NE, Cuevas E, editors. Sea turtles in the North Atlantic \& Wider Caribbean Region. MTSG Regional Report 2020. Report of the IUCN-SSC Marine Turtle Specialist Group. p. 369-401.

GASS J, ECKERT SA. 2006. Bycatch mortality of leatherback turtles in Trinidad's artisanal gillnet fishery [master]. Durham: Nicholas School of the Environment and Earth Sciences, Duke University. 31 p.

Guada H, Sole G. 2000. WIDECAST Plan de acción para la recuperación de las tortugas marinas de Venezuela, Informe Técnico del PAC. UNEP Caribbean Environment Programme, Kingston, Jamaica. 112 p.

Hamann M, Godfrey MH, Seminoff JA, Arthur K, BARATA PCR, BJORndAL KA, Bolten AB, Broderick AC, CAMpbell LM, CARreras C, et al. 2010. Global research priorities for sea turtles: informing management and conservation in the 21 st century. Endanger Species Res. 11: 245-269.

Hamelin KM, James MC, Ledwell W, HuntingTON J, MARTIN K. 2017. Incidental capture of leatherback sea turtles in fixed fishing gear off Atlantic Canada. Aquat Conserv: Mar Freshwat Ecosyst. 27 (3): 631-642.

Hays GC, Houghton JDR, Myer AE. 2004. PanAtlantic leatherback turtle movements. Nature. 24: 522.

JAmes MC, OtTENSMeyer CA, Myers RA. 2005. Identification of high-use habitat and threats to leatherback sea turtles in northern waters: New directions for conservation. Ecol Lett. 8 (2): 195-201.

Koch V, Nichols WJ, Peckham H, DE la Toba V. 2006. Estimates of sea turtle mortality from poaching and bycatch in Bahía Magdalena, Baja California Sur, Mexico. Biol Conserv. 128: 327-334.

Meager JJ, Limpus CJ. 2012. Marine wildlife stranding and mortality database annual report
2011. III. Marine turtle. Conservation Technical and Data Report. 3: 1-46.

[NALWG] The Northwest Atlantic LeatherBACK WorkIng Group. 2019. Dermochelys coriacea (Northwest Atlantic Ocean subpopulation) (errata version published in 2020). The IUCN Red List of Threatened Species 2019: e.T46967827A184748440. https://dx.doi.org/ 10.2305/IUCN.UK.2019-2.RLTS.T46967827 A184748440.en.

Nicolau L, Ferreira M, Santos J, Araújo H, Sequeira M, Vingada J, Eira C, Marçalo A. 2016. Sea turtle strandings along the Portuguese mainland coast: spatio-temporal occurrence and main threats. Mar Biol. 163: 1-13.

Rodríguez G, Morales F. 2000. Comunidades bentónicas del sistema del Lago de Maracaibo. In: RodríGuez G, editor. El Sistema de Maracaibo. Biología y ambiente. 2nd ed. Caracas: Instituto Venezolano de Investigaciones Científicas (IVIC). p. 75-85.

Rojas-CAÑIZAles D, EsPinOZA-RodRíguez N, Petit-Rodríguez M, Palmar J, Mejías-BalSAlobre C, WildermanN N, Barros T, BARRIOS-GARRIDO H. 2020. Marine turtle mortality in a southern Caribbean artisanal fishery: a threat for immature green turtles. Reg Stud Mar Sci. 38: 101380.

Rondón-Médicci M, Buitrago J, Guada HJ, ECKERT K. 2011. Estimación poblacional, rutas migratorias y características morfométricas, de la tortuga cardón (Dermochelys coriacea Vandelli 1761) en las playas de Cipara y Querepare, Península de Paria, Venezuela, durante las temporadas de anidación 2000-2006. Bol Investig Mar Costeras. 40 (2): 309-326.

Rondón-Médicci M, Guada H, Buitrago J, Balladares C. 2015. Cardon, Dermochelys coriacea. In: RODRÍGUEZ JP, GARCÍA-RAWLINS A, Rojas-SuÁrez F. editors. Libro rojo de la fauna venezolana. Caracas: Provita y Fundación Empresas Polar. 470 p.

Stewart K, Johnson C, Godfrey M. 2007. The minimum size of leatherback at reproductive 
maturity, with a review of sizes for nesting females from the Indian, Atlantic and Pacific Ocean basins. J Herpetol. 17: 123-128.

Vélez-Rubio GM, Estrades A, Fallabrino A, TomÁs J. 2013. Marine turtle threats in Uruguayan waters: insights from 12 years of stranding data. Mar Biol. 160: 2797-2811.

Wallace BP, Kot CY, Dimatteo AD, Lee T, CROWDER LB, LEWISON R.L. 2013. Impacts of fisheries bycatch on marine turtle populations worldwide: toward conservation and research priorities. Ecosphere. 4 (3): 1-49. 
